\title{
Baranzan's People: An Ethnohistory of the Bajju of the Middle Belt of Nigeria By Carol V. McKinney
}

Reviewed by Jeremy McNabb

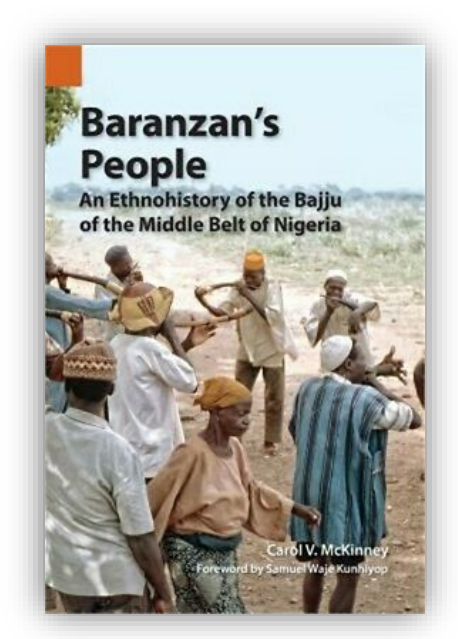

Dallas TX: SIL International 2019

Reproducing the history and essence of a group of people onto the printed page is not simply a matter of observing and taking notes. To really relay the spirit of a people, one must get inside their community, abandon oneself, and then take the time to reflect on what one has absorbed. In Baranzan's People: An Ethnohistory of the Bajju of the Middle Belt of Nigeria, Carol V. McKinney employs her fieldwork, research, and interviews with Bajju people to produce a wellrounded ethnohistory of this group, giving special attention to the relatively modern integration and assimilation of Christianity with the Bajju culture.

The comprehensive nature of this work brings to mind Evans-Pritchard's Witchcraft, Oracles, and Magic Among the Azande, as a deep dive into the practices of the Bajju people. Thirty years of reflection on her life with the Bajju has given the author a wealth of wellconsidered theological and anthropological reflections. It is thoroughly readable in its narration whether one is an undergraduate just beginning classes or long-time professional with dozens of ethnographies already stacked precariously on their bookshelves. A surprisingly engaging piece of prose, with delightfully retold anecdotes of Bajju culture, Baranzan's People could eventually become a classic.

As with any ethnographic work, McKinney treats the reader to a tour of legal proceedings, gender roles, hunting practices, views on witchcraft, the spiritual realm, taboos, birth, marriage, and death. Curiosities abound.

Of particular interest to this reader was the attention given to the introduction, assimilation, and indigenization of Christianity among the Bajju people. The negative aspects of colonization should always be a major concern for any anthropologist and this is doubly true when missionary efforts are underway, but using the Bajju's own reports of Christianity's entrance into their area, McKinney paints a picture of a missionary effort that is far more complex and nuanced than some of the more coercive efforts that have taken place in other areas of the world and at other times in history.

McKinney details how, prior to Christianization, the Bajju people held to a purposefully vague notion of a god, believing that he exists and that he dwells above them in the sky, but with little else to be said. The mechanics of their religion centered more on nkut or witchcraft, than any kind of deity. For them, the introduction of Christianity was accepted as a biographical entry on the god they already believed to exist. Oddly enough to us, in their eyes, Christian taboos about alcohol and sex indicated to the Bajju (who had similar taboos) that Christianity was valid and appealing as a religion.

With the aid of several helpful charts, the author also explains that, just as it did in the West, the Bajju Church quickly divided itself. The resulting denominations, however, unlike European Christianity where theology was the central issue, had more to do with how much of Bajju culture remained in their churches. Her records reflect the Bajju's collective wrestling matches with the concepts of polygamy, supernatural dreams, visions, a persistent belief in witchcraft, and a localized version of what other regions would call the "prosperity gospel." McKinney also tracks arguments by other anthropologists that the Bajju should return to their preChristian beliefs, and how these assertions have mostly 
fallen on deaf ears with the Bajju people. For example, despite some problematic developments such as the mandated shaving of certain hairstyles for educational opportunities and the import of Western Christianity's "purity culture," the overall position of women and children have advanced too much for their society to desire to return to a system in which women were ruled by a secret, and sometimes vindictive, council of menthe abvoi. McKinney demonstrates that the overall thrust to accept and remain in Christianity has come from those who have, traditionally, been of marginal value to the community prior to Christianity's coming. First-hand accounts of this, which are so key in lending credibility to McKinney's claims (mostly) on behalf of Christianity, are in ready supply.

Beyond anthropologists, Baranzan's People provides perspective to students of church history and theology. Bajju Christianity has not been around long enough to have appeared on history scholars' radar, much less make an impact on the global academic scene, but the unique ways in which denominations have developed and the myriad of points at which indigenous culture has been integrated into Christianity is valuable to anyone interested in the development of doctrine and the decentering of European norms.

What few critiques I have of this otherwise excellent book relate to turns of phrases which are, in this reviewer's experience, inappropriate and have fallen out of favor within inter-faith and psychological communities. The term "Judeo-Christian" suggests a unity and unanimity between Judaism and Christianity regarding certain beliefs which are more nuanced and divided than such a term suggests. Judaic beliefs tend to be erased by this term more frequently than not. Secondly, the unfortunate use of the word "retarded" instead of "developmentally disabled" reflects, perhaps, the negative view some Bajju people have of developmentally disabled people, but is nevertheless hurtful for English readers. Future editions could remedy these insensitivities without affecting the rest of the text.

Overall, Baranzan's People is informative and specific without being dry or repetitious. It offers up a small piece of history that is largely missing from standard church history texts. McKinney's theological observations of the Bajju's belief system walk the reader through an otherwise difficult gap between cultures. I would recommend it for any student or scholar of anthropology, missiology, theology, or church history.

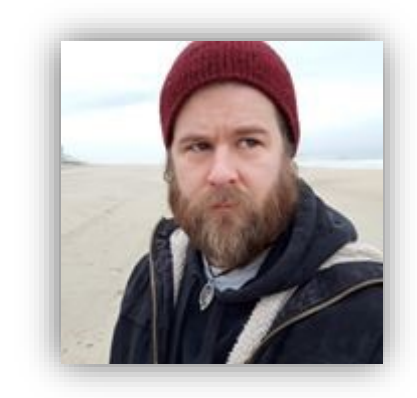

Jeremy M. McNabb is a graduate student in the Master of Arts in Theological and Cultural Anthropology program at Eastern University. He has a Bachelor's Degree in Biblical and Theological Studies from Regent University.

Author email: jeremymcnabb.1@gmail.com 